\title{
Effect of internet of things on road freight industry
}

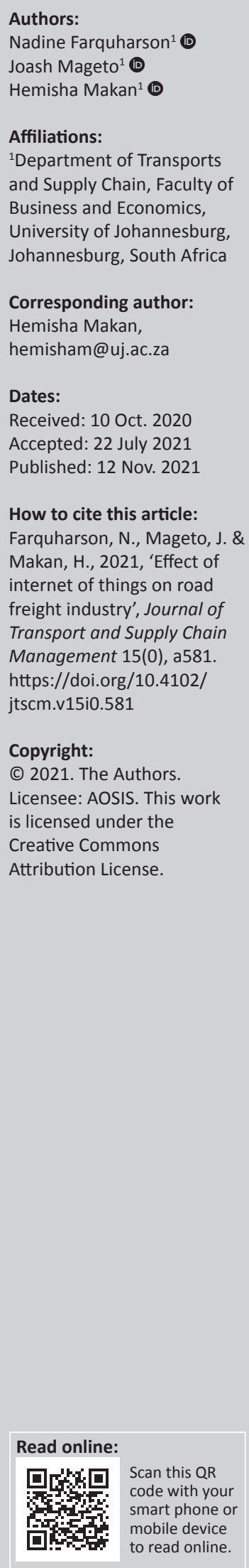

Background: Evolution in global supply chain has created numerous complexities especially in the transportation of freight. Some of the complexities include ever increasing operational cost, long lead-times, limited end-to-end visibility and raw material supply disruptions because of adverse weather conditions. To improve processes and keep abreast of competition, it is vital for businesses to leverage their operations on current technologies. Internet of things (IoT) technology is one of the innovative technologies that can bring about radical transformations to freight transportation. Despite the promising capabilities of IoT, research on its application and effect on road freight sector in developing economies is scanty.

Objectives: The purpose of this article is to establish the likely effect of IoT on the road freight sector. This article identifies IoT technologies used in road freight and establishes the relationship between the drivers and benefits of implementing IoT technologies.

Method: Structured questionnaires were sent to employees working within the road freight industry within South Africa. The data were subjected to factor analysis for dimension reduction. Regression analysis helped to establish the relationship between drivers and benefits of IoT.

Results: The benefits of IoT were operational effectiveness and improved decision making. The drivers of implementing IoT were identified as asset visibility and the need for real-time information sharing. The main effect of IoT on road freight sector is increased asset visibility. The challenges impeding implementation of IoT include high cost of installation, skills gap, fear of hacking and cyberattacks.

Conclusion: Road freight transport managers are advised that IoT can be a strategic tool that uses smart sensor technologies that provide visibility of assets to reduce operational costs and improve decision making. The article contributes to logistics management literature by enumerating the IoT technologies used in the road freight sector in South Africa. It also highlights that IoT provides end-to-end visibility resulting in improved decision-making for optimal operations.

Keywords: internet of things; IoT technologies; road freight; visibility; regression analysis.

\section{Introduction}

The internet of things (IoT) has caused a phenomenal shift in the way that logistics industries operate. Globally, an estimated 5.2 billion people utilise the internet as of April 2021 (Internet World Stats 2021:1). The internet has transformed the way organisations plan and execute their operations through the use of networked ordinary 'things', which are interconnected using the right software and online information infrastructure; that are now articulated as smart objects (Al-Fuqaha et al. 2015:1497; Federal Transit Administration [FTA] 2017:1). Smart objects are computerised, autonomous or physical objects that consist of components such as processors, actuators, sensors and network systems, which are linked to the internet with a capability to collect and analyse data continuously (González García et al. 2017:7). Al-Fuqaha et al. (2015:1497) further elaborated that smart objects communicate seamlessly whilst simultaneously coordinating and integrating processes.

The smart objects or 'things' use sensors and software that enable businesses to monitor their operations for efficiency and effectiveness (FTA 2017:1). These interconnected objects are known as IoT, which refers to a digital network of interconnected 'things' or objects that communicate with one another via the basis of wireless technological systems (Atzori, Lera \& Morabito 2010:2788; Rivera \& Goasduff 2014; Zhou, Chong \& Ngai 2015:1). In a road freight transport environment, the interconnected objects can support vehicle to vehicle, vehicle to person and vehicle to infrastructure communication thus improving visibility and decision-making (Dong et al. 2021:391). Internet of things can transform the road freight industry by introducing 
autonomous tracking and tracing of freight and monitoring and maintaining temperature of goods in transit (Atzori et al. 2010:2790; FTA 2017:1).

Road freight transportation is a key logistics activity for most organisations within the supply chain as it dominates the first and last mile of freight transportation and it accounts for a significant proportion of freight transport cost (Macioszek 2017:147). The demand for road freight transport service has been increasing especially in South Africa, for instance, there was a $3.6 \%$ increase in the volume of goods transported by road freight in 2019 compared with the 2018 figures (Statistics South Africa 2019:2). Despite the significance of the road freight sector to the economy especially in South Africa where it moves over $76 \%$ of freight, it is faced by numerous challenges such as theft whilst goods are in transit, erratic protests posing security risks to crew, vehicle and freight and ineffective cold chain transportation (Liang et al. 2016:3). Road freight transport is also blamed for many other problems such as road congestion, accidents and carbon dioxide gas emissions to the environment. Thus, managing road freight operations diligently is important to help mitigate the associated huge cost and operational waste (Dlodlo 2015:19). This calls for research on this sector to identify ways in which the cost of transporting freight can be minimised to improve organisational competitiveness. As such, Dong et al. (2021) argued that emerging technologies such as IoT offers an opportunity for road freight transport operators to manage their operations efficiently and effectively to increase their bottom line and competitiveness, however evidence of IoT benefits is limited. Prior studies (FTA2017:3; Zhou et al. 2015:1) highlighted that implementing advanced technologies such as IoT can bring about extensive benefits such as augmented visibility and transparency and enhanced operational practices resulting in cost reduction, risk reduction and increased traceability of goods in transit. However, the actual effect of IoT on the road freight transport sector especially in developing countries is still unknown.

Some of the prior studies focussed on the benefits and challenges associated with IoT implementation (Atzori et al. 2010; Chen et al. 2014; Haddud et al. 2017) and macro benefits of IoT to society (FTA 2017). Some other studies examined the impact of emerging technologies on freight transport (Dong et al. 2021) and some identified IoT as one of the technologies when attaining smart mobility cities (Zahraei, Kurniawan \& Cheah 2019). In addition, other focus areas have been IoT enabled green logistics (Chhabra, Singh \& Kumar 2021), adoption of digitalisation in the logistics and supply chain management industry using IoT (Herold et al. 2021) and IoT as one of the technologies in transport integration (Ravish \& Rangaswamy 2020). Therefore, there is limited research regarding the effects of IoT on the road freight industry as also claimed by (Lee \& Lee 2015:432; Mishra et al. 2016:1347). This article will bridge the gap by investigating the likely effects of IoT on the road freight industry. Highlights from the article provide insights into the management within the road freight industry and academia on the likely strategic effect of implementing IoT. Management will also gain information regarding the potential challenges when implementing IoT technologies. Thus, the following research questions are answered in this article:

- What are the various types to IoT technologies implemented by road freight industry?

- What is the relationship between drivers and benefits of implementing IoT in road freight industry?

- What are the challenges faced by road freight industry when implementing IoT?

\section{Literature review}

Technological advancements have resulted in the transformation of business processes and making it easier to adapt to the changing landscape and achieve competitive advantage. Barreto, Amaral and Pereira (2017:1245) argued that with technological progression customer demand is increasingly dynamic, which creates new service delivery challenges for organisations, especially in the road freight industry. As a result, businesses implement advanced technologies to create more value for customers. Internet of things is seen as a technology that can bring about value to customers who move freight.

\section{Internet of things}

Internet of things is fundamentally used to connect physical and digital objects by utilising the internet and information systems (Hwang et al. 2017). The physical objects have capabilities to sense, analyse data and perform specific tasks through information sharing and synchronising decisions, interrelate and connect with humans in addition to other smart objects (Haddud et al. 2017:1060). These physical objects become smart when equipped with ICT systems, processing networks, sensors and internet protocols (AlFuqaha et al. 2015:1497). Furthermore, effectively collecting, analysing and transforming data transmitted from smart objects into useful information, offers remarkable visibility of all activities across the supply chain and provides early warning of situations that can be remedied immediately (Ben-Daya, Hassini \& Bahroun 2019). Ellis, Morris and Santagate (2015) explained that IoT has the potential to reduce time between data capture and decision-making, which ultimately helps management to react to real-time changes and allow heightened agility and responsiveness. Generally, the FTA (2017) identifies IoT technology components as sensors, gateways, networks, standards and data analysis tools as illustrated in Table 1.

$\mathrm{Xu}, \mathrm{He}$ and Li (2014), stated that radio frequency identification (RFID) is one of the foundational technologies for IoT whereby microchips are used to emit identification information through wireless communication and allows readers to monitor and track objects that have RFID tags. In addition, there are four main layers to IoT network: (1) a sensing layer that combines 'things' such as sensors, actuators and RFID tags, (2) a networking layer, which enables the transfer of information by means of a wireless network, (3) a service layer that requires middleware technology, which allows the integration of 
TABLE 1: Internet of things technological components.

\begin{tabular}{ll}
$\begin{array}{l}\text { Technological } \\
\text { component }\end{array}$ & Description \\
\hline Sensors & $\begin{array}{l}\text { A sensing system observes and creates data without the need } \\
\text { for human observation. Sensors can collect information about } \\
\text { position, occupancy, proximity, velocity, pressure, sound, } \\
\text { temperature and light. }\end{array}$ \\
Gateways & $\begin{array}{l}\text { Gateways allow for signals generated by sensors to be } \\
\text { communicated to networks and vice versa; gateways facilitate } \\
\text { bidirectional communication between the sensor and the } \\
\text { network. }\end{array}$ \\
Networks & $\begin{array}{l}\text { Networks transmit real-time data collected by sensors to } \\
\text { other devices. }\end{array}$ \\
Standards & $\begin{array}{l}\text { Data collected by sensors and transmitted over the network } \\
\text { are aggregated so they can be analysed; standards facilitate } \\
\text { interoperable data handling, processing and storage. }\end{array}$ \\
Data Analysis Tools & $\begin{array}{l}\text { Analyses of loT data: } \\
\text { Aggregate and communicate information about individuals } \\
\text { and their preferences } \\
\text { Can be communicated back through the network to make } \\
\text { adjustment in the physical world } \\
\text { Provide information on patterns that can help us optimise } \\
\text { safety, efficiency and customer experience }\end{array}$ \\
\hline
\end{tabular}

Source: Federal Transit Administration (FTA) 2017

IOT, Internet of things.

service and application and (4) an interface layer whereby information is displayed and interaction with the system is allowed (Ben-Daya et al. 2019; Xu et al. 2014).

In addition to this, Lee and Lee (2015) and Ben-Daya et al. (2019) defined five IoT technologies: (1) which allows tracking and tracing capabilities and identification and transmission of information, (2) wireless sensor network (WSN) used to track and monitor various devices such as temperature, location and movement of good through the use of sensors, (3) middleware which is a software that allows communication with devices such as actuators, RFID tags and sensors, (4) cloud computing which is an internet-based platform where various computing resources are shared and (5) IoT application which allows device to device and human to device interaction.

Taking this into account, it is evident that the use of IoT technology can bring about phenomenal economic, operational, social and environmental benefits. Moreover, the implementation of IoT brings about a dynamic shift within the logistics industry by providing innovative functionality and capabilities for communicating between people and things and providing an autonomous synchronisation between 'things' that ultimately enhance visibility, adaptability, accessibility and agility within the supply chain including the road freight industry (Chen et al. 2021).

\section{The road freight industry}

Road freight transportation is considered to be a flexible mode of transport, providing door-to-door services. Furtado and Frayret (2015:436) added that the freight transport industry needs to provide services that are versatile yet simultaneously low cost to accommodate the various product ranges available and concurrently pursue pioneering ways to become more sustainable. Shao, Xu and Li (2019) enumerated that transportation is considered as a non-value-adding activity, which devour an exorbitant amount of money and resources. In addition, $\mathrm{Xu}$ et al. (2019:89), affirmed that freight transport companies are facing numerous extremity such as safety, efficiency, quality, reliability, flexibility and punctuality, which has created a demand for efficient fleet management at a reduced cost and empty mileage. Addressing and mitigating the challenges mentioned here can be done through the advanced implementation of IoT technologies. In a study carried out by Ebrahim (2019), the author explained that it is important to understand the impact of IoT within the transport industry specifically because the application of this technology is revolutionising the transport industry and ultimately contributing to economic growth both globally and locally. The deployment of IoT within the road freight industry can reduce the risk of shipment delays by informing the various stakeholders of possible disruptions related to travel such as traffic diversion, road condition and analysing vehicle usage for optimal utilisation (Manavalan \& Jayakrishna 2019).

Choosakun, Chaiittipornwong and Yeom (2021:5) highlighted that it is crucial for systems to exchange information between themselves and other applications in the road freight industry in order to warrant the success of implementing IoT technologies. A standard architecture of knowledge that enables interoperability is essential for the prosperity of this exchange of information. As such, from a global perspective, the United States Department of Transport (USDOT) has implemented an Architecture Reference for Cooperative and Intelligent Transportation (ARC-IT), with the aim of addressing challenges and supporting technology advances, which can improve surface transportation systems (USDOT 2021). Programme goals from USDOT are as follows:

- To promote integration of data from multiple wirelessly connected applications and infrastructure in order to facilitate key decision-making on safety, mobility and environmental applications

- To evaluate the benefits and effects of deploying advanced technologies in the real-world instead of a simulated test environment

- To resolve political and financial issues of various realworld deployments (Han 2020:4).

Architecture Reference for Cooperative and Intelligent Transportation provides a framework that allows planning, defining and integrating intelligent transportation systems (ITS) (USDOT 2021). Intelligent transport systems (ITS), as per the USDOT (2021) is defined as the application of advanced sensor, computer, electronics and communication technologies and management strategies - in an integrated manner - to improve the safety and efficiency of the surface transportation system'. The purpose of ITS is to ensure efficiency within the road transportation by providing realtime information. Furthermore, Monje (2016) argued that there are profound impacts of integrating transportation infrastructure such as reducing commuting time, having no transportation fatalities and mitigating negative effect of climate change. With the increased use in advanced technologies such as IoT and access to data, numerous advantages are accrued, which include:

- Connected vehicle that will enable drivers to refrain from dangerous situations 
- Transportation planners can better track cargo in real time

- Freight deliverables can be automated by the use of robotics, which can maximise efficiency

- There is huge potential to reduce accidents, vehicle losses and damages to infrastructure by implementing a fully automated vehicle (Monje 2016).

Despite the benefits identified, it is important to note that Monje(2016) focused generally on United States transportation, not on IoT effect on freight transport in developing countries such as South Africa, thus leaving a gap.

However, looking at the South African Department of Transport, such innovation is not yet implemented. According to Dlodlo (2015), there is a need within South Africa, to promote sustainable transport systems, which can be carried out with the potential of IoT technologies. Furthermore, Dlodlo (2015) analysed various public transport entities within South Africa, such as South African National Roads Agency (SANRAL), Road Traffic Management Corporation (RMTC), Cross-border Road Traffic Agency and the Road Traffic Infringement Agency and areas were identified whereby IoT technology can be used to resolve issues pertaining to road transport management. This is indicative that although IoT technologies are used by some of the private road freight enterprises within South Africa, it has not yet been implemented on a governmental level. In addition, Ebrahim (2019:2) observed that IoT can be used to help reduce traffic congestion within South Africa. Traffic congestion has an extensive impact on road transportation in South Africa with Cape Town and Pretoria contributing the most in terms of congestion levels as shown in Figure 1. According to the 2018 INRIX rank, commuters travelling within Cape Town, spend a total of $162 \mathrm{~h}$ in traffic each year with Pretoria not far behind, with commuters spending a total of $143 \mathrm{~h}$ in traffic each year (INRIX 2019).

There have been a few applications that use advanced technology to help mitigate traffic congestion such as that created by Waze ${ }^{\mathrm{TM}}$, however, there is still a huge margin for the implementation of IoT technologies to help alleviate

\begin{tabular}{|c|c|c|c|}
\hline URBAN ARIEA & $\begin{array}{l}2018 \text { IMPACT RANK } \\
\text { (2017) }\end{array}$ & $\begin{array}{l}\text { HOURES LOST IN } \\
\text { CONGESTION }\end{array}$ & $\begin{array}{l}\text { YEAR OVER YEAR } \\
\text { CHANGE }\end{array}$ \\
\hline Cape Town & 95 (96) & $162(28)$ & $-4 \%$ \\
\hline Pretoria & $64(71)$ & $143(54)$ & $9 \%$ \\
\hline Johnanesbur & $61(63)$ & $119(82)$ & $3 \%$ \\
\hline Durban & 141(133) & 72 (160) & $-8 \%$ \\
\hline$\approx$ Port Ellzabetr & $75(77)$ & 71 (162) & $1 \%$ \\
\hline Bloemfontein & 165(174) & $62(178)$ & $8 \%$ \\
\hline
\end{tabular}

Source: INRIX, 2019, INRIX, viewed 11 June 2021, from http://inrix.com/products/traffic/ FIGURE 1: INRIX ranking for the top six cities in South Africa. traffic congestion and intelligent routing especially of freight vehicles (Ebrahim 2019:2). According to Ebrahim (2019:4), there is immense possibility for technological advancement in South Africa especially in road transport although the current infrastructure impedes this growth.

\section{Drivers and benefits of internet of things}

Enhanced transparency and visibility of information and material flow across the supply chain are some of the effects of IoT for logistics companies, particularly the road freight industries (Haddud et al. 2017:1061). Shao et al. (2019) supported this by explicitly stating that IoT technology can provide opportunity for the road freight transport industry by providing accurate real-time information, allows tracking and tracing abilities of goods in transit, provides travel history of vehicle and allows the execution of routing plans. In addition, a study performed by Bogataj, Bogataj and Hudoklin (2017), revealed that IoT can be used to track ambient conditions such as the humidity, gas concentration and temperature, which ultimately assist in reducing postharvest loss within a supply chain.

These effects are supported in numerous studies related to real-time information exchange and the companies' ability to react proactively to movements of physical goods within the road freight industry (Haddud et al. 2017:1061). In a study conducted by Chen et al. (2014:351), the authors proposed that IoT has numerous capabilities. Location sensing and sharing location information is one of the capabilities, which include information about the geographical position, collected from the GPS, cell-ID and RFID. Internet of things applications also comprises mobile asset tracking, which utilises location sensing devices and communication functions to monitor and track commodities. Internet of things can also include fleet management whereby management can schedule drivers and vehicles and obtain real-time information on the location of the vehicle and traffic information systems, which provides information regarding traffic conditions by tracking the location of the vehicle (Chen et al. 2014:351). To support this, Ebrahim (2019) added that IoT allows data to be shared between vehicles and important information pertaining to road closure, any traffic-related incidence and finding alternative routes is provided. This ultimately enables management to keep abreast of real-time scenarios and implement contingency plans around deliveries of freight should there be unforeseen situations.

\section{Challenges of internet of things implementation}

There are some challenges that need to be mitigated for IoT to achieve its vision (Coetzee \& Eksteen 2011:5). These challenges include the need for sophisticated infrastructure to support IoT, data management together with security and privacy of business processes. A major challenge for implementing IoT in the road freight industry are the security issues resulting from the lack of common standards around IoT security (Al-Fuqaha et al. 2015:1513). Internet of things is a technology that has the ability to share pertinent information between physical objects and humans. These smart objects 
hold confidential information, which pose as a threat for road freight industries because of the risk of being exposed through cyberattacks. The challenge associated with data management is that incredible quantity of data are required to be processed and stored in order to gain information to make acceptable, value adding decisions (Chen et al. 2014:356). In addition, the services provided by logistics companies that have the investments to implement such infrastructure to support the large amount of data within their networks are very expensive (Al-Fuqaha et al. 2015:1513). Hence, to reap the effects of IoT, it is imperative for the challenges mentioned here to be resolved.

\section{Research methodology}

The aim of this article is to establish the effect of IoT technology implementation on road freight transport. To achieve this aim, a quantitative approach was followed within the positivist paradigm. A descriptive survey design was implemented to collect primary data at one point in time for this article (Collis \& Hussey 2003:374). Employees working for road freight enterprises within South Africa were the unit of analysis. Given that there is no official database of road freight operators in South Africa, a Google search was used to identify and randomly select 120 road freight companies within South Africa. These companies were contacted via telephone and through email and a total of four companies allowed for data to be collected. From these four companies who granted permission, there were an estimated 1000 employees collectively. The estimation of 1000 employees was obtained from Google results and the managers within the four companies. The target sample was 300 employees who met the inclusion criteria of being middle and top managers within the four companies. From the 300 employees who were invited to participate, 81 completed the online questionnaire thus, providing a response rate of $27 \%$. Similar studies have used almost the same sample sizes, for instance, (Islam et al. 2020) used 87 shippers.

The data collection instrument used was a structured questionnaire containing questions that were closed ended. The questionnaire was designed based on the conceptual framework obtained from the literature review. The questionnaire design covered the demographic information, IoT technologies, drivers of IoT technologies and challenges of implementing IoT technologies and benefits of IoT. A fivepoint Likert-style scale was used, which allowed respondents to easily make their preferred selection ranging from strongly disagree (1) to strongly agree (5). Statistical Package for the Social Sciences (SPSS) statistics software system version 25 was used to obtain the descriptive statistics to answer research question one. Factor analysis was conducted for dimension reduction and resulted in two components as reported in Section 'Effect of internet of things drivers on benefits of its implementation'. Regression analysis was conducted in R (see model summary in Table 4) to establish the relationship between drivers of implementing IoT technologies and its benefits.

\section{Ethical considerations}

Based on the university's guidelines, ethical clearance was required and obtained. The clearance certificate code received for this research was 2019TSCM-025HON. Full consent was obtained from participants prior to the commencement of the questionnaires. Anonymity of the organisation and participants was ensured, and information was kept strictly confidential.

\section{Results \\ Demographic results}

The gender split of the majority (54\%) being male is analogous to the study carried out by Kovács and Tatham (2010), which characterises the logistics industry as being male dominant. Most of the respondents involved in IoT implementation were from middle management (46\%) and top management (32\%), with $38 \%$ having between 10 and 19 years of working experience. The working experience of the respondents coincided with the age variable whereby the most recurring age was between 30 and 39 years (74\%). To contribute to the credibility of the research, respondents were required to have in-depth knowledge of the road freight industry, hence the correlation of age and work experience to meet this requirement. When queried about the company's annual turnover, $40 \%$ respondents revealed that the annual turnover was ZAR500 million and above. In the light of this, these employees were working for large enterprises as their turnover was over ZAR51 mn (Olawale \& Garwe 2010:730). Results further revealed that $77 \%$ of the respondents operated directly within the road freight industry, 15\% operated within the IT sector, providing telematic solutions to road freight industry. The various IoT technologies are presented in the following section.

\section{Internet of things technologies applied in road freight industry in South Africa}

There are various technologies available in the market. To determine the IoT technologies implemented in the employees' organisations, respondents were provided with a list and were required to tick the technologies implemented in their firms. Based on the results depicted in Figure 2, smart route sensors together with navigations systems were the highly recognisable

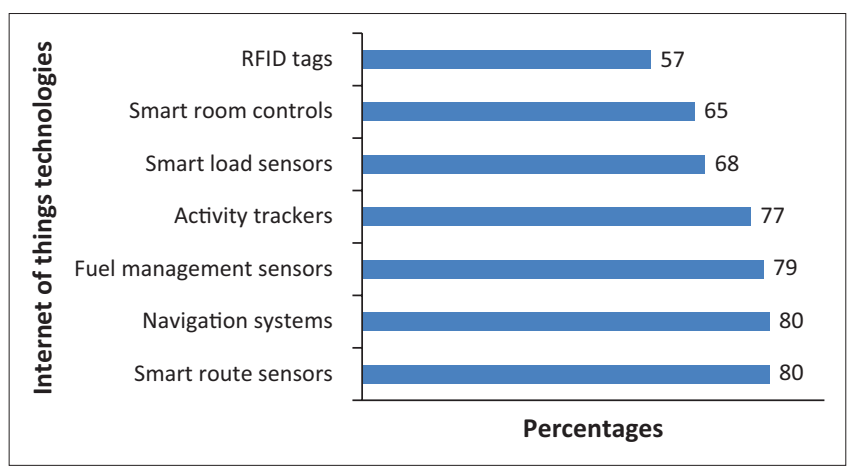

FIGURE 2: Internet of things technologies identified by respondents. 
IoT technologies. Fuel management systems and activity trackers were the second most identifiable IoT technologies. Although RFID tags are well-known technologies, they were not commonly used in the trucking industry compared with smart route sensors and navigation systems as revealed by the sample data.

Similar findings were presented in a study conducted by Sundmaeker et al. (2010:18) whereby technology such as sensor network, location technology, actuators, RFID tags and room sensors were identified as IoT technologies. Internet of things technologies can only be implemented in an organisation when there is a need to be satisfied, which can be referred to as a driver or motivation for implementing IoT.

\section{Drivers for implementing internet of things technologies within the road freight industry}

Figure 3 reveals that the need for critical real-time information exchange and location management systems were the drivers selected by the largest proportions (45\%) of respondent. The finding supports a study by Atzori et al. (2010:2787), which observed that the major aspect for implementing IoT technologies is to improve processes, visibility of goods on transit and efficient transportation of goods. Parcel tracking (43\%) and end-to-end visibility (42\%) were also regarded as significant drivers for implementing IoT technologies within the road freight industry.

\section{Benefits of implementing internet of things technologies within the road freight industry}

The major benefits accrued from implementing IoT include improved customer service (47\%) and cost savings (46\%) as illustrated in Figure 4. Other benefits include improved process simplification, mitigating disruptions and increased driver safety. The least ranked benefit as per the sample used in this article is that IoT mitigates disruption (40\%).

\section{Challenges of implementing internet of things technologies in the road freight industry}

The perceived challenges in implementing IoT technologies within the road freight industry are illustrated in Figure 5. Implementing IoT technologies can be very expensive (42\%)

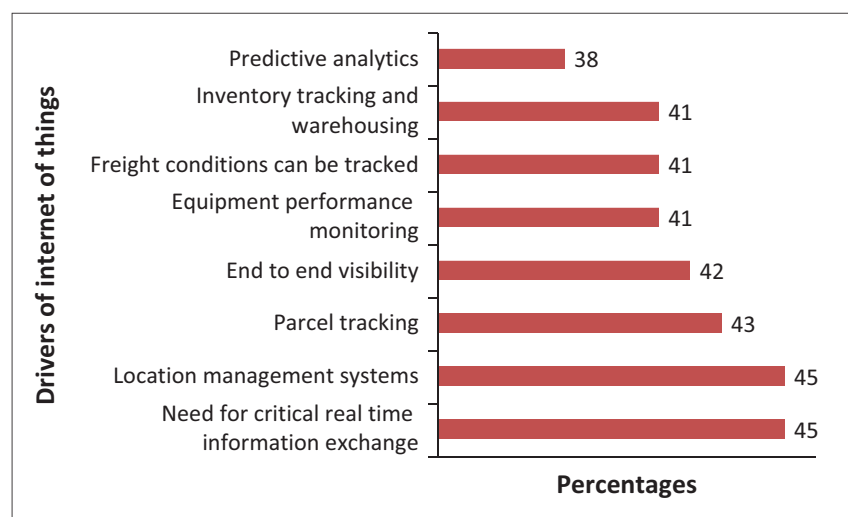

FIGURE 3: Drivers of implementing internet of things. as shown in Figure 5. The second major challenge is the skills gap (41\%), whilst hacking and cyberattacks constituted $40 \%$. Similar challenges in implementing IoT technologies were identified by Al-Fuqaha et al. (2015:1513).

\section{Scale reliability}

The reliability of the scale items for the benefits, drivers and challenges of IoT were tested using Cronbach's alpha. The scales had overall Cronbach's alpha values of $0.880,0.758$, 0.707 for the benefits of IoT, drivers and challenges, respectively, which were all above 0.7 threshold revealing high internal consistency of each of the scales (Pallant 2020).

\section{Relationship between drivers and benefits of Internet of things implementation}

The relationship between the drivers of IoT and benefits of implementing IoT was investigated to advise road freight managers which drivers to focus on to achieve specific benefits. To investigate the effect of drivers of IoT on the benefits, it was important to conduct a dimension reduction to establish the patterns existing amongst the manifest variables. Dimension reduction was conducted using the principal component analysis method and varimax rotation method. The Kaiser-Meyer-Olkin (KMO) measure of sampling adequacy and the Bartlett's test of sphericity were

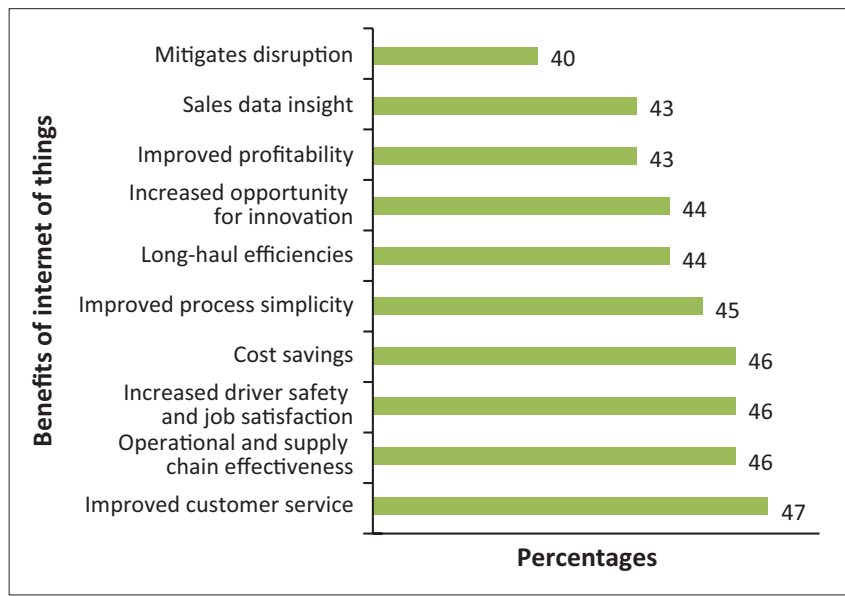

FIGURE 4: Effects of implementing internet of things.

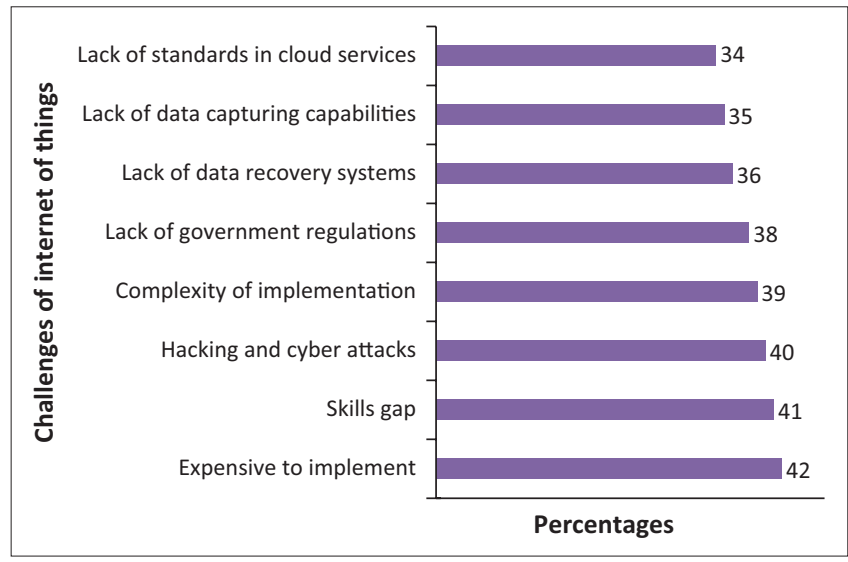

FIGURE 5: Challenges of implementing internet of things. 
tested for each of the scales. The KMO values were 0.748 and 0.728 for the drivers and benefits of IoT constructs, respectively, which were acceptable given that the threshold is 0.6 (Pallant 2020). All the measures were statistically significant on the Bartlett's test of sphericity implying that they were fit for factor analysis.

One item was excluded from further analysis as they were resulting in a cross-loading problem to meet the requirements of factor analysis as argued by Mageto, Prinsloo and Luke (2018). The optimal solution of dimension reduction on the drivers of IoT resulted in extraction of two components as per Table 2. The extracted components explained $60 \%$ of the variance based on eigenvalues greater than 2 . The two drivers of IoT were interpreted as increased visibility of goods in transit (with three items) and real-time information sharing (with four items) from remote locations, which allows for

TABLE 2: Rotated component matrix of drivers and benefits of internet of things.

\begin{tabular}{|c|c|c|c|}
\hline $\begin{array}{l}\text { Unobserved } \\
\text { variables }\end{array}$ & Extracted constructs & Observed variables & $\begin{array}{c}\text { Factor } \\
\text { loadings }\end{array}$ \\
\hline \multirow[t]{7}{*}{ Drivers of loT } & Asset visibility & $\begin{array}{l}\text { Visibility13.1 End-to-end } \\
\text { visibility }\end{array}$ & 0.721 \\
\hline & & $\begin{array}{l}\text { Location } 13.2 \text { Location } \\
\text { management systems }\end{array}$ & 0.763 \\
\hline & & Parcel13.5 Parcel tracking & 0.558 \\
\hline & $\begin{array}{l}\text { Real-time } \\
\text { information sharing }\end{array}$ & $\begin{array}{l}\text { Inventory } 13.3 \text { Inventory } \\
\text { tracking and warehousing }\end{array}$ & 0.685 \\
\hline & & $\begin{array}{l}\text { Predictive13.4 Predictive } \\
\text { analytics }\end{array}$ & 0.827 \\
\hline & & $\begin{array}{l}\text { Equipment13.7 Equipment } \\
\text { performance monitoring }\end{array}$ & 0.788 \\
\hline & & $\begin{array}{l}\text { Conditions } 13.8 \text { Freight } \\
\text { conditions can be tracked }\end{array}$ & 0.793 \\
\hline \multirow[t]{8}{*}{ Benefits of loT } & $\begin{array}{l}\text { Operational } \\
\text { effectiveness }\end{array}$ & $\begin{array}{l}\text { Effectiveness } 14.2 \text { Operational } \\
\text { and supply chain effectiveness }\end{array}$ & 0.645 \\
\hline & & $\begin{array}{l}\text { Improved } 14.3 \text { Improved } \\
\text { customer service }\end{array}$ & 0.722 \\
\hline & & $\begin{array}{l}\text { Saftey } 14.4 \text { Increased driver } \\
\text { safety and job satisfaction }\end{array}$ & 0.771 \\
\hline & & $\begin{array}{l}\text { Efficiencies14.6 Long-haul } \\
\text { efficiencies }\end{array}$ & 0.849 \\
\hline & $\begin{array}{l}\text { Intelligent } \\
\text { decision-making }\end{array}$ & $\begin{array}{l}\text { Mitigates } 14.7 \text { Mitigates } \\
\text { disruption }\end{array}$ & 0.707 \\
\hline & & $\begin{array}{l}\text { Innovation } 14.8 \text { Increased } \\
\text { opportunity for innovation }\end{array}$ & 0.839 \\
\hline & & Insight14.9 Sales data insight & 0.758 \\
\hline & & $\begin{array}{l}\text { Profitability } 14.10 \text { Improved } \\
\text { profitability }\end{array}$ & 0.827 \\
\hline
\end{tabular}

loT, internet of things. predictive analytics and monitoring of freight conditions as also claimed by Dong et al. (2021:391).

Factor analysis was also conducted on the benefits of IoT resulting into two components (after excluding two items because of a cross-loading problem), which explained about $63 \%$ of the total variance based on eigenvalues greater than 1. The components relating to the benefits of IoT would generally be identified as operational effectiveness (component 2) and intelligent decision-making based on literature (component 1 ) as illustrated in Table 2.

The relationship between drivers and benefits of IoT was investigated through correlation analysis and linear regression analysis. Correlation analysis was performed between the drivers of IoT and the two extracted components of the benefits of IoT, that is, operational effectiveness and real-time decisionmaking. A significant positive, although weak relationship was established between intelligent decision-making and inventory tracking and warehousing and need for real-time information exchange as illustrated in Table 3. The weak relationship can be because of the fact that IoT technologies are still emerging in developing countries and only a few road freight operators have embraced it. As such, its true value and potential in this industry has not been realised.

The relationship between operational effectiveness and drivers of IoT was significant but negative and weak with only predictive analytics (Table 4). This finding does not support the existing literature, which argues that predictive analytics capabilities of IoT is likely to result in efficiency and effectiveness of operations (Mageto 2021). However, given the fact that IoT is still in nascent years especially in developing countries, we can argue that its capabilities in improving operational effectiveness have not been realised. It can also be argued that a firm must invest significantly in IoT technologies to achieve the operational effectiveness, however, the level of IoT investment was not investigated in this study.

Making reference to Table 2, a correlation analysis was performed between the extracted components of the drivers of IoT (i.e. asset visibility and real-time information sharing)

TABLE 3: Correlations: Intelligent decision-making and drivers of internet of things.

\begin{tabular}{|c|c|c|c|c|c|c|c|c|}
\hline Variable & $\begin{array}{l}\text { End-to-end } \\
\text { visibility }\end{array}$ & $\begin{array}{l}\text { Location } \\
\text { management } \\
\text { systems }\end{array}$ & $\begin{array}{c}\text { Inventory } \\
\text { tracking and } \\
\text { warehousing }\end{array}$ & $\begin{array}{l}\text { Predictive } \\
\text { analytics }\end{array}$ & Parcel tracking & $\begin{array}{l}\text { Need for } \\
\text { real-time } \\
\text { information } \\
\text { exchange }\end{array}$ & $\begin{array}{l}\text { Equipment } \\
\text { performance } \\
\text { monitoring }\end{array}$ & $\begin{array}{c}\text { Freight } \\
\text { conditions can be } \\
\text { tracked }\end{array}$ \\
\hline Location management systems & $0.348 * *$ & - & - & - & - & - & - & - \\
\hline $\begin{array}{l}\text { Inventory tracking and } \\
\text { warehousing }\end{array}$ & $0.408 * *$ & 0.152 & - & - & - & - & - & - \\
\hline Predictive analytics & $0.305^{* *}$ & 0.027 & $0.597 * *$ & - & - & - & - & - \\
\hline Parcel tracking & $0.264^{*}$ & 0.054 & $0.445 * *$ & $0.254 *$ & - & - & - & - \\
\hline $\begin{array}{l}\text { Need for real-time information } \\
\text { exchange }\end{array}$ & $0.330 * *$ & 0.2 & $0.311 * *$ & $0.354 * *$ & 0.164 & - & - & - \\
\hline $\begin{array}{l}\text { Equipment performance } \\
\text { monitoring }\end{array}$ & $0.338 * *$ & 0.121 & $0.436 * *$ & $0.536 * *$ & 0.083 & $0.396 * *$ & - & - \\
\hline Freight conditions can be tracked & 0.19 & 0.048 & $0.338 * *$ & $0.448 * *$ & $0.225^{*}$ & $0.274^{*}$ & $0.551 * *$ & - \\
\hline Intelligent decision-making & 0.108 & 0.091 & $0.226 *$ & 0.204 & 0.223 & $0.229 *$ & -0.015 & 0.061 \\
\hline
\end{tabular}

*, Correlation is significant at 0.05 level; control variable - Operational_effectiveness; **, Correlation is significant at 0.01 level. 
TABLE 4: Correlations: Operational effectiveness and drivers of internet of things.

\begin{tabular}{|c|c|c|c|c|c|c|c|c|}
\hline Variables & $\begin{array}{l}\text { End-to-end } \\
\text { visibility }\end{array}$ & $\begin{array}{l}\text { Location } \\
\text { management } \\
\text { systems }\end{array}$ & $\begin{array}{l}\text { Inventory } \\
\text { tracking and } \\
\text { warehousing }\end{array}$ & $\begin{array}{l}\text { Predictive } \\
\text { analytics }\end{array}$ & Parcel tracking & $\begin{array}{l}\text { Need for } \\
\text { real-time } \\
\text { information } \\
\text { exchange }\end{array}$ & $\begin{array}{l}\text { Equipment } \\
\text { performance } \\
\text { monitoring }\end{array}$ & $\begin{array}{c}\text { Freight } \\
\text { conditions can be } \\
\text { tracked }\end{array}$ \\
\hline Location management systems & $0.335 * *$ & - & - & - & - & - & - & - \\
\hline $\begin{array}{l}\text { Inventory tracking and } \\
\text { warehousing }\end{array}$ & $0.394 * *$ & 0.11 & - & - & - & - & - & - \\
\hline Predictive analytics & $0.286^{*}$ & -0.029 & $0.589 * *$ & - & - & - & - & - \\
\hline Parcel tracking & $0.248^{*}$ & 0.033 & $0.413 * *$ & 0.215 & - & - & - & - \\
\hline $\begin{array}{l}\text { Need for real-time information } \\
\text { exchange }\end{array}$ & $0.316 * *$ & 0.175 & $0.277^{*}$ & $0.325 * *$ & 0.119 & - & - & - \\
\hline $\begin{array}{l}\text { Equipment performance } \\
\text { monitoring }\end{array}$ & $0.342 * *$ & 0.106 & $0.458 * *$ & $0.555^{*} *$ & 0.089 & $0.413 * *$ & - & - \\
\hline Freight conditions can be tracked & 0.185 & 0.021 & $0.346 * *$ & $0.461 * *$ & 0.217 & $0.271^{*}$ & $0.558 * *$ & - \\
\hline Operational_effectiveness & -0.015 & 0.157 & -0.141 & $-0.235^{*}$ & -0.011 & -0.047 & -0.094 & -0.133 \\
\hline
\end{tabular}

*, Correlation is significant at 0.05 level; control variable - real-time decision-making; ${ }^{* *}$, correlation is significant at 0.01 level.

and the composite measure of the benefits of IoT as illustrated in Table 5. There is a statistically significant positive correlation between the benefits of IoT and asset visibility. However, there is no correlation between benefits of IoT and real-time information sharing. This implies that there is likely no known link between the benefits of IoT and real-time information sharing amongst the sample population.

The linear regression model between the benefits of IoT as the outcome variable with asset visibility and real-time information sharing as predictor variables was conducted (see Table 6).

The linear regression model was tested using the R packages given their high modelling capability compared with other statistical packages. As expected, asset visibility as an IoT driver is a statically significant $(p<01)$ predictor of benefits of IoT amongst road freight enterprises. However, real-time information sharing is not a statistically significant predictor of the benefits of IoT, but it is positively associated. The model developed explained only $7.466 \%$ of the variance as per the R-squared value obtained. The low R-squared value implies that the model is weak and has no predictive power. The low R square implies that the benefits of IoT in the road industry might be explained by many other factors that were not investigated in the article. This would be true given that the IoT technologies are not used in isolation but together with other technologies that were not investigated in this research. The weak model as depicted by the low $\mathrm{R}$ square value can be explained by the fact that IoT might not be fully accepted by practitioners in the road freight industry, especially in developing countries. In addition, $\mathrm{Lu}$, Papagiannidis and Alamanos (2021) argued that the true value of new technologies can be realised once they are embraced by a critical mass and when the intensity of use is

TABLE 5: Correlations of drivers and benefits of loT.

\begin{tabular}{lccc}
\hline Variable & Asset_Visibility & Real_time_Info & Benefits_loT \\
\hline Asset_Visibility & 1 & - & - \\
Real_time_Info & $0.362^{* *}$ & 1 & - \\
Benefits_loT & $0.268^{*}$ & 0.04 & 1 \\
\hline
\end{tabular}

*, statistically significant $(p<0.05) ; * *$, statistically significant $(p<0.01)$. high - this is not the case in South Africa's Road freight industry regarding IoT.

\section{Discussion}

To understand the effects of IoT on the road freight industry, three key questions were investigated. The first question sought to investigate the various types of IoT technologies implemented by managers in the road freight industry. The results reveal several IoT technologies being used in the road freight sector including smart route sensors, navigation systems and fuel management systems. The smart sensors are used to monitor environmental conditions such as humidity, pressure and temperature of cargoes and send real-time reports to the control room for effective decision making (Dong et al. 2021:399). Other IoT technologies include activity trackers and load sensors. RFID tags were also identified as an IoT technology; however, they were not commonly used amongst the sampled respondents. The finding on IoT technologies such as sensors, RFID, actuators, location systems and GPS tracking system supports prior

TABLE 6: Regression model results: $\mathrm{R}$ regression model and output.

\begin{tabular}{|c|c|c|c|c|}
\hline Variable & Beta & (Intercept) & $\begin{array}{c}\text { Asset } \\
\text { visibility }\end{array}$ & $\begin{array}{l}\text { Real_time } \\
\text { info_share }\end{array}$ \\
\hline \multicolumn{5}{|l|}{ Residuals $\dagger$} \\
\hline Min & -1.07962 & - & - & - \\
\hline $1 Q$ & -0.35240 & - & - & - \\
\hline Median & 0.04538 & - & - & - \\
\hline $3 Q$ & 0.39920 & - & - & - \\
\hline Max & 0.63941 & - & - & - \\
\hline \multicolumn{5}{|l|}{ Coefficients: } \\
\hline Estimate & - & 3.54224 & 0.23395 & -0.03915 \\
\hline Standard error & - & 0.41955 & 0.09455 & 0.07814 \\
\hline$t$-value & - & 8.443 & 2.474 & -0.501 \\
\hline $\operatorname{Pr}(>|t|)$ & - & $1.3 \mathrm{e}-12 * * *$ & $0.0155 *$ & 0.6178 \\
\hline $\begin{array}{l}\text { Residual standard } \\
\text { error }\end{array}$ & $\begin{array}{l}0.4621 \text { on } 78 \text { degrees } \\
\text { of freedom }\end{array}$ & - & - & - \\
\hline$R$-squared & 0.07466 & - & - & - \\
\hline Adjusted R-squared: & 0.05093 & - & - & - \\
\hline F-statistic & 3.147 on 2 and 78 DF & - & - & - \\
\hline$p$-value & 0.0485 & - & - & - \\
\hline
\end{tabular}

Min, minimum; Max, maximum

$\dagger$, Call: $\operatorname{Im}($ formula $=$ loT_Benefits Asset_visibility + Real_time.info_share); $\$$, Signif. codes: $0 * * *, 0.001 ; * *, 0.01 ; *, 0.05 ;$ ". 0.1 " 1 . 
research within the road freight sector (Dlodlo 2015; Haddud et al. 2017:1083; Muñuzuri et al. 2020; Sundmaeker et al. 2010:18; Zahraei et al. 2019:39). In addition, Muñuzuri et al. (2020) generally classified IoT technologies used in the transport sector into tracking, information management and navigation systems. The IoT technologies help managers to collect adequate data regarding the location of freight, environmental conditions within the freight location, likely delays and detection of incidences and likely disruptions (Dlodlo 2015; Taliaferro et al. 2021). Thus, allowing management to make decisions based on real-time data relayed electronically to prevent or minimise likely disruptions in freight deliveries. Therefore, IoT technologies are multitudinous and might vary from industry to industry, based on the activities or operations performed. Whilst many of the studies have identified the technologies based on qualitative approach (Golpîra, Khan \& Safaeipour 2021), in this article, a quantitative approach is followed and the actual practice regarding IoT in the road freight sector is reported, thus, guiding managers and technology providers the likely growth areas regarding the IoT technologies.

The second research question explored the relationship between drivers and benefits of implementing IoT in the road freight industry. Firstly, the drivers of implementing IoT include the need for real-time information exchange, location management, tracking, end-to-end visibility and predictive analytics regarding the movement of freight. The findings support Muñuzuri et al. (2020) study, which established that the need for automated data acquisition and processing and optimisation in the management of transport operations as the key drivers of IoT in firms. Therefore, the drivers of IoT are summarised as end-to-end asset visibility and need for real-time collection, analysis and sharing of actionable information. The identified drivers are likely to result in improved customer service because of real-time visibility of their cargo and ultimately delivering operational and supply chain effectiveness. The drivers are likely to result in increased driver safety, cost savings and process simplification, which imply that IoT technologies will ease management time so that they can focus on customer service.

Secondly, the benefits of IoT highlighted in this article include improved customer service, operational effectiveness, driver safety, cost savings and process simplification. The findings support Vadhwani and Thakor (2020:55) study that identified improved operational effectiveness, road safety and detection of incidents as benefits of IoT implementation. Similarly, (Dlodlo 2015; Mishra et al. 2016), claimed that IoT is beneficial to transportation management, for example, improved safety, speed control, visibility, fuel monitoring, tire pressure monitoring, planned maintenance and load management. In addition, the finding on the benefits of IoT also supports Golpîra et al. (2021) study, which claimed that IoT results in process simplification, cost reduction and operational efficiency as the major benefits of implementation IoT in road freight sector. The analysis of the data highlighted the benefits as being operational effectiveness and intelligent decision making. The findings reveal further that end-to-end asset visibility as a driver of IoT significantly influences the operational effectiveness and the quality of decisions made by managers who have implemented IoT technologies in the road freight sector. The observation supports study by (Atzori et al. 2010; Golpîra et al. 2021; Muñuzuri et al. 2020). To reap the benefits associated with the implementation of IoT such as enhanced security of freight, vehicle and equipment management and human resources (Taliaferro et al. 2021) requires managers of road freight operations to be diligent in the implementation process with clear objectives to be achieved. Finally, this article establishes that the drivers of IoT, that is, end-to-end asset visibility and real-time sharing of actionable information has a positive association with operational effectiveness and improved decision making, although only asset visibility resulted in a statistically significant relationship supporting (Dlodlo 2015; Golpîra et al. 2021). The practical benefits of IoT resulting from asset visibility and real-time information sharing to road freight operators include sharing of vehicle and driver data and driving behaviour, cargo conditions, location engine status, vehicle data and security, thus supporting Taliaferro (2021). Therefore, the benefits of IoT can be fully realised within the road freight industry once the technology is embraced by many of the players. Currently only a few of the players (especially the large enterprises) have partially implemented IoT in South Africa and other developing countries. Hence, its true benefits are yet to be realised.

The third research question examined the challenges of implementing IoT in the road freight industry. The challenges include high cost of installation, skill gap, hacking and cyberattacks. The findings support study by (Al-Fuqaha et al. 2015:1513; Dong et al. 2021). The challenges related to IoT implementation can further be classified into (1) technology, for example, security, compatibility with existing systems, connectivity issues and analysis capabilities as also claimed by Bafana (2017). Road freighters can also face a challenge related to (2) business, that is, developing the right business model for IoT to help improve the bottom line of the enterprise. The challenges can also relate to (3) society, for example, personal privacy as data collected from 'things' may contain personal details and lack of proper regulatory standards to manage IoT deployment may pose a risk to users (Bafana 2017). Thus, the identified challenges can be viewed from the three perspectives, that is, technology, business and society.

\section{Conclusion}

Global shifts in the world economy have resulted in fundamental changes in the operations of businesses including the road freight industries. The need to be in the competitive forefront means moving with the radical changes and improving business processes to gain competitive advantage. Technology plays a vital role in ensuring success for businesses in this modern era, it is thus imperative for businesses, including the road freight industry to adopt innovative technologies such as IoT. IoT technologies can improve enterprise processes and operations. However, currently, IoT 
technologies have neither been fully defined nor identified (Golpîra et al. 2021). Whilst it is difficult to list all the IoT technologies, this article identified those used within the road freight sector. These included RFID tags, navigation systems, smart room controls, smart route sensors, fuel management sensors, activity trackers and smart load sensors. It is also important to note that new IoT technologies are being developed daily and more additions to the list are expected in the near future. Implementing IoT technologies could be because of various instigating factors other than competition. Some of the drivers identified included equipment performance monitoring, asset visibility, location management systems, tracking of freight conditions and the need for critical time information exchange. Implementation of IoT in the road freight sector can generally be motivated by the need to have end-to-end asset visibility and real-time sharing of actionable information. These drivers result in many road freight companies implementing IoT technologies to streamline processes and to ensure that operations are conducted in an efficient and effective manner. Effects of the implementation of IoT technologies within the road freight industry include increased driver safety, operational and supply chain effectiveness, improved customer service and job satisfaction. Regardless of the drivers compelling road freight industries to implement IoT technologies and effects associated with the implementation of IoT technologies, numerous challenges wereidentified, which can resultin the delaysinimplementation. Findings in this research revealed that vulnerability of cyberattacks and hacking, skill gap and the mere fact that it is expensive and complex to implement poses challenges in implementing IoT technologies within the road freight industry. It is important to highlight that asset visibility presents the main benefit of implementing IoT to road freight managers. This implies that managers may be in a position to know the location of an asset and its condition in real-time. Road freight operations can also be monitored using the installed IoT technologies, thus improving visibility and transparency.

Managers in the road freight industry are informed of which IoT technologies are being implemented and the likely benefits of implementing the technologies in their enterprises. Implementing these technologies can be capital-intensive given that in some cases the desired skills may not be available within the organisations or the industry at large. Despite the costs involved, it is argued in this article that the benefits are more as the adopters are likely to be highly competitive. With the implementation of IoT technologies, managers can have a comprehensive view on driver behaviour patterns and visibility of goods in transit. The practical use of the identified IoT technologies enables management within the road freight industry to reduce cost, the kilometres travelled, as well as wear and tear of vehicles. In addition, IoT technologies can also assist in reducing emissions from vehicles and avoid congestions by taking alternative routes thereby creating a sustainable and efficient operation. The responsibility of top management in implementing IoT in road freight is fundamental in establishing the standards and providing the required resources and support during the implementation phases. Therefore, IoT offers an opportunity for managers to combine smart 'things' and internet to draw knowledge and insights for better decision making as also claimed by Golpîra et al. (2021).

Whilst the findings reported in this article make a novel contribution to logistics management research, a few limitations were identified. The data used in this research were collected at one point in time. A longitudinal study may present a more holistic picture regarding the implementation of IoT technologies. The scope of the article can also be expanded in future to include other industries such as manufacturing, public transport, marine transport, amongst others. Findings were also limited to the opinions of employees from a developing country perspective and thus generalisations can be done cautiously. Future research may collect data from developed countries and compare the results. This article followed a quantitative approach, future research can apply a mixed method to gain more insights into the topic. Finally, future research may investigate the potential financial and customer satisfaction improvements accrued from IoT implementation amongst private and public road freight transporters across the Southern Africa region.

\section{Acknowledgements}

The authors would like to thank the Department of Transport and Supply Chain Management for granting permission for this study to be conducted.

\section{Competing interests}

The authors have declared that no competing interest exists authors have declared that no competing interest exist.

\section{Authors' contributions}

N.F. conceptualised the study and collected data. H.M. developed the article and did final editorials. J.M. analysed the data, edited the article and authorised for publication.

\section{Funding information}

This research received no specific grant from any funding agency in the public, commercial or not-for-profit sectors.

\section{Data availability}

The data that support the findings of this study are available on request from the corresponding author, H.M.

\section{Disclaimer}

The views and opinions expressed in this article are those of the authors and do not necessarily reflect the official policy or position of any affiliated agency of the authors.

\section{References}

Al-Fuqaha, A., Guizani, M., Mohammadi, M., Aledhari, M. \& Ayyash, M., 2015 'Internet of things: A survey on enabling technologies, protocols, and applications' IEEE Communications Surveys \& Tutorials 17(4), 2347-2376. https://doi. org/10.1109/COMST.2015.2444095

Atzori, L., lera, A. \& Morabito, G., 2010, 'The internet of things: A survey', Computer Networks 54(15), 2787-2805. https://doi.org/10.1016/j.comnet.2010.05.010 
Bafana, A., 2017, Three major challenges facing loT, viewed 16 November 2020, from https://iot.ieee.org/newsletter/march-2017/three-major-challenges-facing-iot. html.

Barreto, L., Amaral, A. \& Pereira, T., 2017, 'Industry 4.0 implications in logistics: An overview', Procedia Manufacturing 13, 1245-1252. https://doi.org/10.1016/j. promfg.2017.09.045

Ben-Daya, M., Hassini, E. \& Bahroun, Z., 2019, 'Internet of things and supply chain management: A literature review', International Journal of Production Research 57(15-16), 4719-4742. https://doi.org/10.1080/00207543.2017.1402140

Bogataj, D., Bogataj, M. \& Hudoklin, D., 2017, 'Mitigating risks of perishable products in the cyber-physical systems based on the extended MRP model', International Journal of Production Economics 193, 51-62. https://doi.org/10.1016/j. ijpe.2017.06.028

Chen, S., Xu, H., Liu, D., Hu, B. \& Wang, H., 2014, 'A vision of IoT: Applications, challenges, and opportunities with china perspective', IEEE Internet of Things Journal 1(4), 349-359. https://doi.org/10.1109/JIOT.2014.2337336

Chen, Y.T., Sun, E.W., Chang, M.F. \& Lin, Y.B., 2021, 'Pragmatic real-time logistics management with traffic loT infrastructure: Big data predictive analytics of freight
travel time for Logistics 4.0 ', International Journal of Production Economics travel time for Logistics 4.0', International Journal
108157. https://doi.org/10.1016/j.ijpe.2021.108157

Chhabra, D., Singh, R.K. \& Kumar, V., 2021, 'Developing IT-enabled performance monitoring system for green logistics: A case study', International Journal of monitoring system for green logistics: A case study', International Journal of
Productivity and Performance Management. https://doi.org/10.1108/ Productivity and
IJPPM-12-2020-0678

Choosakun, A., Chaiittipornwong, Y. \& Yeom, C., 2021, 'Development of the cooperative intelligent transport system in Thailand: A prospective approach', Infrastructures 6(3), 1-36. https://doi.org/10.3390/infrastructures6030036

Coetzee, L. \& Eksteen, J., 2011, 'The Internet of things-promise for the future? An introduction', in 2011 IST-Africa Conference Proceedings, IEEE, Gaborone, Botswana, pp. 1-9.

Collis, J. \& Hussey, R., 2003, Business research: A practical guide for undergraduate and postgraduate students, Palgrave Macmillan, Houndmills.

Dlodlo, N., 2015, 'The internet of things in transport management in South Africa', Paper presented at the 2015 International Conference on Emerging Trends in Networks and Computer Communications (ETNCC), IEEE, Windhoek, Namibia, pp 19-26.

Dong, C., Akram, A., Andersson, D., Arnäs, P.O. \& Stefansson, G., 2021, 'The impact of emerging and disruptive technologies on freight transportation in the digital era: Current state and future trends', The International Journal of Logistics Management 32(2), 386-412. https://doi.org/10.1108/IJLM-01-2020-0043

Ebrahim, R., 2019, 'Disruptive transport technologies and the future of transport in South Africa', Southern African Transport Conference, CSIR International Convention Centre, Pretoria, South Africa, July 08-11, 2019.

Ellis, S., Morris, H.D. \& Santagate, J., 2015, 'loT-enabled analytic applications revolutionize supply chain planning and execution', International Data Corporation (IDC) White Paper, viewed 14 June 2021, from www.idc.com.

Federal Transit Administration (FTA), 2017, Report to Congress on Internet of Things. FTA Report No. 0099, U.S. Department of Transportation, Washington, DC, viewed 08 June 2021, from https://www.transit.dot.gov/about/research-innovation.

Furtado, P. \& Frayret, J., 2015, 'Proposal sustainability assessment of resource sharing in intermodal freight transport with agent-based simulation', Ifac-papersonline 48(3), 436-441. https://doi.org/10.1016/j.ifacol.2015.06.120

Golpîra, H., Khan, S.A.R. \& Safaeipour, S., 2021, 'A review of logistics internet-ofthings: Current trends and scope for future research', Journal of Industria Information Integration 22, 100194. https://doi.org/10.1016/j.jii.2020.100194

González García, C., Meana Llorián, D., Pelayo García-Bustelo, B.C. \& Cueva Lovelle, J.M., 2017, 'A review about smart objects, sensors, and actuators', Internationa Journal of Interactive Multimedia and Artificial Intelligence 4(3), 7-10. https://doi. org/10.9781/ijimai.2017.431

Haddud, A., DeSouza, A., Khare, A. \& Lee, H., 2017, 'Examining potential benefits and challenges associated with the internet of things integration in supply chains' Journal of Manufacturing Technology Management 28(8), 1055-1085. https:// doi.org/10.1108/JMTM-05-2017-0094

Han, S., 2020, 'A survey and insights on deployments of the connected and autonomous vehicles in US', arXiv Preprint arXiv:2008.04379.

Herold, D.M., Ćwiklicki, M., Pilch, K. \& Mikl, J., 2021, 'The emergence and adoption of digitalization in the logistics and supply chain industry: An institutiona perspective', Journal of Enterprise Information Management. https://doi. org/10.1108/JEIM-09-2020-0382

Hwang, G., Lee, J., Park, J. \& Chang, T.W., 2017, 'Developing performance measurement system for Internet of Things and smart factory environment', International Journal of Production Research 55(9), 2590-2602. https://doi.org/10.1080/00207 543.2016.1245883

Islam, S., Uddin, M.J., Shi, P., Sharif, T. \& Ahmed, J.U., 2020, 'Exploring shippers' motivations to adopt collaborative truck-sharing initiatives', International Journa of Physical Distribution \& Logistics Management 51(5), 528-550. https://doi. org/10.1108/IJPDLM-10-2019-0303

INRIX, 2019, INRIX, viewed 11 June 2021, from http://inrix.com/products/traffic/.

Internetworldstats.com., 2021, World Internet users statistics and 2021 world population stats, viewed 11 June 2021, from https://www.internetworldstats. com/stats.htm.
Kovács, G. \& Tatham, P., 2010, Quantitative and qualitative perspectives on gender in humanitarian logistics, Leadership through the Gender Lens. Women and Men in Organisations, pp 262-275, Hanken School of Economics, Helsinki.

Lee, I. \& Lee, K., 2015, 'The internet of things (IoT): Applications, investments, and challenges for enterprises', Business Horizons 58(4), 431-440. https://doi. org/10.1016/j.bushor.2015.03.008

Liang, K., Van de Hoef, S., Terelius, H., Turri, V., Besselink, B., Mårtensson, J. et al., 2016, 'Networked control challenges in collaborative road freight transport' European Journal of Control 30, 2-14. https://doi.org/10.1016/j. European Journa

Lu, Y., Papagiannidis, S. \& Alamanos, E., 2021, 'Adding "things" to the internet: Exploring the spillover effect of technology acceptance', Journal of Marketing Management 37(7-8), 1-25.

Macioszek, E., 2017, 'First and last mile delivery-problems and issues', in G. Sierpińsk (ed.), Scientific and Technical Conference Transport Systems Theory and Practice, pp. 147-154, Springer, Cham.

Mageto, J., 2021, 'Big data analytics in sustainable supply chain management: A focus on manufacturing supply chains', Sustainability 13(13), 7101. https://doi. org/10.3390/su13137101

Mageto, J., Prinsloo, G. \& Luke, R., 2018, 'Logistics outsourcing and performance of manufacturing small and medium-sized enterprises in Nairobi', The Southern African Journal of Entrepreneurship and Small Business Management 10(1), 1-11. https://doi.org/10.4102/sajesbm.v10i1.162

Manavalan, E. \& Jayakrishna, K., 2019, 'A review of Internet of Things (IoT) embedded sustainable supply chain for industry 4.0 requirements', Computers \& Industrial Engineering 127, 925-953. https://doi.org/10.1016/j.cie.2018.11.030

Mishra, D., Gunasekaran, A., Childe, S.J., Papadopoulos, T., Dubey, R. \& Wamba, S., 2016, 'Vision, applications and future challenges of internet of things: A bibliometric study of the recent literature', Industrial Management \& Data Systems 116(7), 1331-1355. https://doi.org/10.1108/IMDS-11-2015-0478

Monje, C., 2016, How the Internet of Things (IOT) can bring U.S. Transportation and Infrastructure into the 21st century, viewed 07 July 2021, from https://www. commerce.senate.gov/2016/6/how-the-internet-of-things-iot-can-bring-u-stransportation-and-infrastructure-into-the-21st-century.

Muñuzuri, J., Onieva, L., Cortés, P. \& Guadix, J., 2020, 'Using loT data and applications to improve port-based intermodal supply chains', Computers \& Industrial Engineering 139, 105668. https://doi.org/10.1016/j.cie.2019.01.042

Olawale, F. \& Garwe, D., 2010, 'Obstacles to the growth of new SMEs in South Africa: A principal component analysis approach', African Journal of Business Management 4(5), 729-738.

Pallant, J., 2020, SPSS survival manual: A step by step guide to data analysis using IBM SPSS, 7th edn., Open University Press, London.

Ravish, R. \& Rangaswamy, S., 2020, 'Integrated mode of transport: A predictive model for route guidance', International Journal of Intelligent Unmanned Systems. https://doi.org/10.1108/IJIUS-09-2020-0040

Rivera, J. \& Goasduff, L., 2014, Gartner says a thirty-fold increase in internet-connected physical devices by 2020 will significantly alter how the supply chain operates, Gartner, London.

Shao, S., Xu, G. \& Li, M., 2019, 'The design of an loT-based route optimization system A smart product-service system (SPSS) approach', Advanced Engineering Informatics 42, 101006. https://doi.org/10.1016/j.aei.2019.101006

Statisticss South Africa, 2019, Land transport survey (preliminary) April 2019, Statistical Release P7162, Stats SA, Pretoria.

Sundmaeker, H., Guillemin, P., Friess, P. \& Woelfflé, S., 2010, 'Vision and challenges for realising the internet of things', Cluster of European Research Projects on the Internet of Things, European Commision 3(3), 34-36.

Taliaferro, A., Ernst, R., Ahmed, U., Harolikar, A. \& Ray, S., 2021, Creating IoT ecosystems in transportation, viewed 16 July 2021, from https://www2.deloitte. com/us/en/insights/focus/internet-of-things/transportation-iot-internet-ofthings-ecosystem.html.

U.S. Department of Transport (USDOT), 2021, Architecture reference for cooperative and intelligent transportation, viewed 03 July 2021, from https://local.iteris.com/ arc-it/index.html.

Vadhwani, D. \& Thakor, D., 2021, 'Statistical analysis of vehicle detection in Zuber Patel, Shilpi Gupta, Nithin Kumar Y. B. (eds.), the ITS application for monitoring the traffic and road accident using internet of things', in Advances in VLSI and embedded systems, pp. 55-70, Springer, Singapore.

Xu, G., Li, M., Luo, L., Chen, C.H. \& Huang, G.Q., 2019, 'Cloud-based fleet management for prefabrication transportation', Enterprise Information Systems 13(1), 87-106. https://doi.org/10.1080/17517575.2018.1455109

$\mathrm{Xu}$, L.D., He, W. \& Li, S., 2014, 'Internet of things in industries: A survey', IEEE Transactions on Industrial Informatics 10(4), 2233-2243. https://doi.org/10.1109/ TII.2014.2300753

Zahraei, S.M., Kurniawan, J.H. \& Cheah, L., 2019, 'A foresight study on urban mobility: Singapore in 2040', Foresight 22(1), 37-52. https://doi.org/10.1108/FS-05-2019-0044

Zhou, L., Chong, A.Y. \& Ngai, E.W., 2015, 'Supply chain management in the era of the internet of things', International Journal of Production Economics 159, 1-3. https://doi.org/10.1016/j.ijpe.2014.11.014 